\title{
Different dietary fats influence serum and tissue lipids and anti-cardiolipin antibody levels in autoimmune-prone NZB/W F1 mice
}

\author{
Shih-Chen Chang ${ }^{1}$, Bor-Luen Chiang ${ }^{2}$, Wen-Mien $\mathrm{Wu}^{1}$ and Bi-Fong Lin ${ }^{1 *}$ \\ ${ }^{1}$ Laboratory of Nutritional Sciences, Department of Agricultural Chemistry, College of Agriculture, \\ National Taiwan University, Taipei, Taiwan 10617, Republic of China \\ ${ }^{2}$ Graduate Institute of Clinical Medicine, College of Medicine, National Taiwan University, Taipei, Taiwan 10617, \\ Republic of China
}

(Received 10 April 1998 - Revised 12 November 1998 - Accepted 16 November 1998)

\begin{abstract}
To investigate the influence of different dietary fats on lipids and anti-cardiolipin antibody levels, autoimmune NZB/W F1 mice were fed on diets containing $200 \mathrm{~g}$ dietary fat as palm oil, lardsoyabean oil $(1: 1, \mathrm{w} / \mathrm{w})$, soyabean oil, rapeseed oil or fish oil/kg. In addition, each dietary fat group was divided into an early-feeding group with feeding from 2 months of age, and a latefeeding group with feeding from 5 months of age. Serum levels of triacylglycerol, phospholipid, cholesterol and anti-cardiolipin antibody were measured at regular intervals, and mice were killed at the age of 7 months for analysis of hepatic lipid and fatty acids. The results showed that hepatic triacylglycerol and cholesterol contents were lower in mice fed on fish oil than in those fed on palm oil. In contrast, hepatic phospholipid content was higher in mice of the fish oil group than in those of the other four dietary fat groups. Composition profiles for both hepatic and renal oleic acid (18:1n-9), linoleic acid $(18: 2 n-6)$ and eicosapentaenoic acid $(20: 5 n-3)$ were similar to those of the dietary fats in mice of both early-feeding and late-feeding groups. Fish oil intake decreased arachidonic acid $(20: 4 n-6)$ concentration in kidney tissue but not in liver tissue. Serum triacylglycerol, cholesterol and phospholipid levels were lower in mice fed on fish oil than in those fed on palm oil. Immunoglobulin (Ig) M anti-cardiolipin antibody was lower for the fish oil group than for the other groups. The IgG anti-cardiolipin antibody level was significantly lower in mice fed on fish oil compared with that of the palm oil group only in the early-feeding group. There was a positive correlation between serum IgM anti-cardiolipin antibody and phospholipid levels (early-feeding group $r$ 0.902, $P<0.05$; late-feeding group $r 0.894, P<0.05$ ). These findings suggest dietary fish oil may affect both lipid levels and anti-cardiolipin antibody, contributing to alleviation of the autoimmune process in autoimmune-prone NZB $\times$ NZW F1 mice.
\end{abstract}

\section{Systemic lupus erythematosus: Dietary fat: Fish oil: Cardiolipin: Autoimmunity}

Systemic lupus erythematosus (SLE) is characterized by the presence of a hetergenous group of antibodies cross-reactive with cardiolipin, phospholipid, DNA, nucleoprotein and certain surface antigens (Theofilopoulos et al. 1989). Anticardiolipin antibody has been demonstrated in the sera for both human and murine lupus, and its presence has been closely related to venous and arterial thrombosis, thrombocytopenia, neurological diseases and recurrent fetal loss (Lockshin et al. 1985; McNeil et al. 1991). Cardiolipin is a mitochondrial dianionic and tetra-acylated phospholipid, and anti-cardiolipin antibody has been found to cross-react with negatively-charged phospholipids, such as phosphotidylserine and phosphotidylinositol (Rauch et al. 1984; Eilat et al. 1986; Harris et al. 1987).
Autoimmune-prone NZB/W F1 mice fed on a high-fat diet, which was composed of equal amounts of lard and soyabean oil, developed more severe disease and had a shorter lifespan (Lin et al. 1996). In addition, higher amounts of dietary fat can also affect the level of anticardiolipin antibody and fatty acid concentrations in NZB/ W F1 mice (Lin et al. 1997b). However, the role of anticardiolipin antibodies in the pathogenesis of this disease has not been clearly elucidated. Studies have shown that an increase in vascular diseases is noted only in SLE patients with high serum triacylglycerol levels, suggesting that serum triacylglycerol level is closely related to production of anti-cardiolipin antibodies and subsequent vascular diseases (Hashimoto et al. 1992; MacGregor et al. 1992). 
Dietary $n$-3 fatty acids have been shown to affect spleen and macrophage fatty acid composition (Chapkin et al. 1991; Robinson et al. 1993a). Plasma cholesterol level was found to be affected by the degree of saturation of dietary fat (Fernandez et al. 1997). Dietary fats with different degrees of saturation or their $n-3: n-6$ fatty acid value might have a critical effect on the serum levels of triacylglycerol, cholesterol and phospholipid, and subsequent antiphospholipid antibody production, which may result in further pathological damage in patients with SLE.

Although dietary fish oil has been shown to reduce the level of immunoglobin (Ig)G anti-double-stranded DNA antibody levels by regulation of cytokine expression (Fernandes et al. 1994) and to reduce proteinuria and prolong lifespan in autoimmune-prone NZB/W F1 mice (Robinson et al. 1993b), only a few studies concerning the effect of fat nutrition on anti-cardiolipin antibody production in autoimmune-prone NZB/W F1 mice have been documented (Lin et al. 1997b). The present study investigated the effect of different dietary fats on hepatic lipid and hepatic and renal fatty acid composition, and further on serum levels of triacylglycerol, cholesterol, phospholipid and anti-cardiolipin antibody in autoimmune-prone mice.

\section{Materials and methods}

Animals and diets

Female NZB $\times$ NZW F1 (B/W F1) mice (6 weeks old) were purchased from the Jackson Laboratory (Bar Harbor, ME, USA). The mice were housed individually in stainless-steel wire cages and fed on a non-purified diet (Lab Rodent Chow; Ralson Purina, St Louis, MO, USA). The animal room was maintained on a $12 \mathrm{~h}$ light $-12 \mathrm{~h}$ dark cycle and at constant temperature $\left(25 \pm 2^{\circ}\right)$ and humidity. Each diet group comprised twelve mice. Animal care and handling conformed to the Guide for the Care and Use of Laboratory Animals (National Research Council, 1985).
The five diets used in the experiment all contained $(\mathrm{g} / \mathrm{kg})$ : 200 casein (Sigma Chemical Co., St Louis, MO, USA), 3 methionine (Sigma Chemical Co.), 250 sucrose (Taiwan Sugar Co., Taipei, Taiwan), 250 maize starch (Roquatte, Paris, France), $50 \alpha$-cellulose (J. Bettenmaier \& Söhne, Ellwangen-Holzmühle, Germany), 2 choline (Sigma Chemical Co.), 35 AIN-76 mineral mixture (American Institute of Nutrition, 1977), 10 AIN-76 vitamin mixture (American Institute of Nutrition, 1977), 200 fat. The fat sources used in the five experimental diets were $(\mathrm{g} / \mathrm{kg}): 200$ palm oil (President Co., Taipei, Taiwan), 200 soyabean oil (Taiwan Sugar Co.), 100 lard (Ya-Sern Co., Taipei, Taiwan) and 100 soyabean oil (lard-soyabean oil), 200 rapeseed oil (Cheil Industries Corp., Taipei, Taiwan), or 180 fish oil (President Co.) and 20 safflower oil (President Co.). DL- $\alpha$-Tocopherol $(100 \mathrm{mg} / \mathrm{kg}$ diet; $50 \mathrm{mg}$ tocopherol equivalents $/ \mathrm{kg}$ ) was added to each diet and the final vitamin $\mathrm{E}$ contents of the diets were $80,62,74,96$ and $120 \mathrm{mg}$ tocopherol equivalents $/ \mathrm{kg}$ diet for palm oil, lard-soyabean oil, soyabean oil, rapeseed oil and fish oil respectively. The differences in vitamin E contents of the dietary fats were not adjusted because of their different oxidation potentials. The hepatic vitamin $\mathrm{E}$ content for the fish oil group was not found to be higher than that of the other four groups (Lin et al. 1997a). The palm oil was decolourized and its $\beta$-carotene content was below the level of detection. The fatty acid pattern of the dietary fat is summarized in Table 1.

The mice were given free access to food. They were weighed twice weekly, and food consumption was measured every $2-3 \mathrm{~d}$. Each of the five dietary fat groups was further divided into early- and late-feeding groups. For the earlyfeeding groups, the mice had been fed on the experimental diets from 2 months of age. For the late-feeding groups, the mice maintained on the non-purified diet, then changed to the experimental diets from the age of 5 months. Six mice from each diet group were killed at 7 months of age, and the rest were maintained on the diets for determination of serum lipids and autoantibody levels, proteinuria and lifespan follow-up to confirm the pathogenic changes of these mice.

Table 1 . The fatty acid pattern $(\mathrm{g} / 100 \mathrm{~g}$ total fatty acids) in the dietary fat

\begin{tabular}{|c|c|c|c|c|c|}
\hline \multirow[b]{2}{*}{ Fatty acid } & \multicolumn{5}{|c|}{ Dietary fat } \\
\hline & Palm oil & Lard-soyabean oil & Soyabean oil & Rapeseed oil & Fish oil \\
\hline $14: 0$ & 3.3 & 0.75 & ND & ND & 5.7 \\
\hline $16: 0$ & 44.7 & $17 \cdot 9$ & $10 \cdot 9$ & 5.2 & 8.2 \\
\hline $16: 1 n-9$ & ND & 1.3 & ND & ND & $7 \cdot 2$ \\
\hline $18: 0$ & 3.9 & 8.0 & 3.9 & 1.6 & 3.3 \\
\hline $18: 1 n-9$ & $40 \cdot 4$ & $33 \cdot 1$ & $22 \cdot 2$ & $53 \cdot 4$ & 11.5 \\
\hline $18: 2 n-6$ & $9 \cdot 3$ & $33 \cdot 8$ & 54.0 & $22 \cdot 9$ & $7 \cdot 2$ \\
\hline $18: 3 n-3$ & ND & 3.9 & 7.2 & $12 \cdot 7$ & $1 . \overline{7}$ \\
\hline $20: 4 n-6$ & ND & ND & ND & ND & 1.8 \\
\hline $20: 5 n-3$ & ND & ND & ND & ND & $26 \cdot 8$ \\
\hline $22: 6 n-3$ & ND & ND & ND & ND & $12 \cdot 6$ \\
\hline SFA & 51.9 & $26 \cdot 7$ & $14 \cdot 8$ & 6.8 & $20 \cdot 2^{*}$ \\
\hline MUFA & $40 \cdot 4$ & 34.4 & $22 \cdot 2$ & $53 \cdot 4$ & $21.9 \dagger$ \\
\hline PUFA & $9 \cdot 3$ & $37 \cdot 7$ & 61.2 & $35 \cdot 6$ & $50 \cdot 1$ \\
\hline$n-3: n-6$ & 0 & 0.12 & 0.13 & 0.55 & 4.6 \\
\hline
\end{tabular}

ND, not detectable; SFA, saturated fatty acid; MUFA, monounsaturated fatty acid; PUFA, polyunsaturated fatty acid; $n-3: n-6, n-3$ fatty acids : $n-6$ fatty acids.

* The trace amounts of other saturated fatty acids were included.

† The trace amounts of other monounsaturated fatty acids were included. 
Serum and liver triacylglycerol, cholesterol and phospholipid level, and analysis of tissues for fatty acid composition

Mice were bled retro-orbitally every month and serum collected for determination of serum triacylglycerol, cholesterol, phospholipid and anti-cardiolipin antibodies. Serum triacylglycerol, cholesterol and phospholipid concentrations were measured by colorimetric procedures using assay kits as described previously (Lin et al. 1997b). To investigate further the effect of fat intake on fatty acid composition, liver and kidney fatty acid compositions were analysed. Six mice from each group were killed by cervical dislocation at the age of 7 months. Livers and kidneys were excised, weighed and an approximately $0.5 \mathrm{~g}$ portion was extracted with chloroform-methanol $(2: 1, \mathrm{v} / \mathrm{v})$ and prepared for further analysis of triacylglycerol, cholesterol and phospholipid according to the method described by Folch et al. (1957). Hepatic triacylglycerol, cholesterol and phospholipid contents were measured by colorimetric methods (Soloni, 1971; Stewart, 1980; Guo et al. 1982). The fatty acid composition was analysed according to the method of Lee et al (1990).

\section{Determination of anti-cardiolipin antibodies}

Serum anti-cardiolipin antibodies levels were determined using ELISA (Rupin et al. 1991). Briefly, ELISA plates were pre-coated with $150 \mu l$ protamine sulfate $(5 \mathrm{mg} / \mathrm{l})$ per well and incubated at room temperature for $6 \mathrm{~h}$. The plates were then washed three times with PBS and coated with $50 \mu \mathrm{l}$ bovine heart cardiolipin (Sigma Chemical Co.; $100 \mu \mathrm{g} / \mathrm{ml}$ absolute ethanol) per well. The control well (cardiolipin-free) was treated with $50 \mu \mathrm{l}$ absolute ethanol as a non-specific binding background. After overnight incubation at $4^{\circ}$, the plates were air-dried at room temperature and washed three times with PBS. Subsequently, the plates were blocked with $200 \mu \mathrm{l}$ post-coat solution $(1 \mathrm{~g}$ gelatin/l PBS) per well and incubated at $37^{\circ}$ for $2 \mathrm{~h}$. After three washes with PBS, sera to be analysed were diluted $1: 100$ or $1: 400$ in a post-coat solution and $50 \mu l$ was added to the appropriate wells. After $3 \mathrm{~h}$ incubation at room temperature, plates were then washed nine times with PBS and peroxidase (EC 1.11.1.7) -conjugated goat anti-mouse $\operatorname{IgG}$ and $\operatorname{IgM}(\gamma-$ and $\mu$-chain-specific; Jackson Inc., West Grove, PA, USA) secondary antibodies were added and incubated at room temperature for $2 \mathrm{~h}$. After nine washes with PBS, adequate substrate was added for colour development and the reaction was stopped with $50 \mathrm{~g}$ SDS/1. Absorbance was determined at $415 \mathrm{~nm}$ (Microplate; BioTek Instrument, Inc., Winooski, VT, USA). The supernatant fraction of monoclonal antibody 9C1A4 isolated from our laboratory was used as a positive control for IgM assays. Sera from one NZB/W F1 mouse which had high anticardiolipin antibody levels was used as a positive control for IgG assays. All the values were assayed in triplicate and derived by subtracting the non-specific binding of each sample.

\section{Statistical analysis}

The significance of difference among groups in the earlyfeeding groups and in the late-feeding groups was analysed statistically by one-way ANOVA and Duncan's multiple range test of the SAS program system (SAS/STAT version 6; SAS Institute Inc., Cary, NC, USA) throughout the study.

\section{Results}

\section{Food intake and growth}

There was no significant difference in feed intake and bodyweight gain among the five different dietary fat groups of mice, either in the early-feeding or the late-feeding groups. The lifespan of mice fed on the fish oil diet $(>450 \mathrm{~d})$ was

Table 2. Hepatic lipids of 7-month-old female NZB/W F1 mice fed on different dietary fats*

(Mean values with their standard errors for the no. of mice per dietary group shown)

\begin{tabular}{|c|c|c|c|c|c|c|c|}
\hline \multirow[b]{2}{*}{ Dietary fat } & \multirow[b]{2}{*}{$n$} & \multicolumn{2}{|c|}{$\begin{array}{c}\text { Triacylglycerol } \\
\text { (mg/g liver) }\end{array}$} & \multicolumn{2}{|c|}{$\begin{array}{l}\text { Cholesterol } \\
\text { (mg/g liver) }\end{array}$} & \multicolumn{2}{|c|}{$\begin{array}{l}\text { Phospholipid } \\
\text { (mg/g liver) }\end{array}$} \\
\hline & & Mean & SE & Mean & SE & Mean & SE \\
\hline \multicolumn{8}{|l|}{ Early-feeding group } \\
\hline Palm oil & 5 & $26 \cdot 07$ & $6 \cdot 90$ & $5 \cdot 26^{a}$ & 0.93 & $14.72^{c}$ & 0.47 \\
\hline Lard-soyabean oil & 6 & $22 \cdot 75$ & $3 \cdot 85$ & $4.06^{a b}$ & $0 \cdot 34$ & $16 \cdot 88^{b}$ & 0.48 \\
\hline Soyabean oil & 5 & 23.74 & $6 \cdot 36$ & $3.79^{b}$ & 0.38 & $16 \cdot 70^{\mathrm{b}}$ & 0.31 \\
\hline Rapeseed oil & 6 & $21 \cdot 77$ & 3.55 & $4.63^{\mathrm{ab}}$ & 0.29 & $15 \cdot 93^{b}$ & 0.19 \\
\hline Fish oil & 5 & $12 \cdot 26$ & $0 \cdot 17$ & $1.91^{\mathrm{c}}$ & 0.07 & $18 \cdot 90^{\mathrm{a}}$ & 0.42 \\
\hline One-way ANOVA & & \multicolumn{2}{|c|}{$P=0.1171$} & \multicolumn{2}{|c|}{$P=0.004$} & \multicolumn{2}{|c|}{$P=0.0001$} \\
\hline \multicolumn{8}{|l|}{ Late-feeding group } \\
\hline Palm oil & 5 & $16 \cdot 35^{a b}$ & $5 \cdot 08$ & $5 \cdot 67^{\mathrm{a}}$ & $0 \cdot 86$ & $15 \cdot 13^{b}$ & 0.32 \\
\hline Lard-soyabean oil & 4 & $20.86^{a b}$ & 1.80 & $4 \cdot 36^{a}$ & 0.35 & $15 \cdot 25^{b}$ & 0.25 \\
\hline Soyabean oil & 6 & $26 \cdot 57^{\mathrm{a}}$ & $3 \cdot 19$ & $4 \cdot 61^{a}$ & 0.46 & $15 \cdot 06^{b}$ & 0.21 \\
\hline Rapeseed oil & 4 & $23 \cdot 13^{a}$ & $5 \cdot 19$ & $5 \cdot 65^{\mathrm{a}}$ & 0.51 & $15 \cdot 29^{b}$ & 0.39 \\
\hline Fish oil & 6 & $11.48^{b}$ & $1 \cdot 18$ & $2 \cdot 62^{b}$ & 0.17 & $16 \cdot 94^{\mathrm{a}}$ & 0.53 \\
\hline One-way ANOVA & & \multicolumn{2}{|c|}{$P=0.0330$} & \multicolumn{2}{|c|}{$P=0.0023$} & \multicolumn{2}{|c|}{$P=0.0051$} \\
\hline
\end{tabular}

a,b,c Mean values in the same column within feeding group with unlike superscript letters were significantly different $(P<0.05$; Duncan's multiple range test).

* Mice were fed for 5 months with a diet containing $200 \mathrm{~g}$ fat $/ \mathrm{kg}$ in the early-feeding group, or fed for 2 months on a diet containing $200 \mathrm{~g}$ fat $/ \mathrm{kg}$ in the late-feeding group. For details of diets and procedures, see pp. 332-333 and Table 1. 
longer than those of mice fed on the other four diets both in the early-feeding group (palm oil 292 (SD 50) d, lardsoyabean oil 282 (SD 22)d, soyabean oil 327 (SD 72)d, rapeseed oil 366 (SD56)d and the late-feeding group (palm oil 234 (SD 24)d, lard-soyabean oil 323 (SD 53) d, soyabean oil 293 (SD 50) d, rapeseed oil 258 (SD 66) d. Twothirds of mice fed on fish oil survived longer than 16 months. However, there was no significant difference in the lifespans among the other four dietary fat groups either in the early-feeding or the late-feeding groups.

\section{Triacylglycerol, cholesterol and phospholipid contents of liver}

The effects of different dietary fats and feeding period on hepatic triacylglycerol, cholesterol and phospholipid contents of NZB/W F1 female mice are summarized in Table 2. Overall, the hepatic triacylglycerol content was lowest in the fish oil group in the late-feeding group. Although the hepatic triacylglycerol content of mice fed on the fish oil diet tended to be the lowest within early-feeding group, there was no significant difference between the five dietary fat groups. For both early-feeding and late-feeding groups, the hepatic cholesterol content of the fish oil-fed group was significantly lower than those of the other groups $(P<$ $0 \cdot 05)$. Mice fed on palm oil had a higher hepatic cholesterol level compared with those of the soyabean oil and fish oil groups in the early-feeding groups $(P<0 \cdot 05)$. However, the hepatic phospholipid level was lowest in the palm oil-fed group of the early-feeding group. In contrast, phospholipid contents were significantly higher in mice fed on fish oil $(P<0.05)$.

\section{Liver and kidney fatty acid composition}

The fatty acid composition of liver and kidney could be affected by dietary fat, as shown in Tables 3 and 4 . The oleic acid (18:1n-9) compositions of both palm oil and rapeseed oil were higher than those of lard-soyabean oil, soyabean oil and fish oil (Table 1). The tissue fatty acid compositions reflected this dietary fat pattern for both liver and kidney oleic acid with palm oil $>$ rapeseed oil $>$ lard-soyabean oil $>$ soyabean oil $>$ fish oil. The linoleic acid $(18: 2 n-6)$ compositions of liver and kidney was highest in the soyabean oil group and lowest in the palm oil and fish oil groups, reflecting the pattern in the dietary fat. Thus, the profiles for both oleic acid and linoleic acid composition in murine tissues reflected the composition profiles for these fatty acids in the dietary fats. For palmitic acid (16:0), palmitoleic acid (16:1n-9) and stearic acid (18:0), however, the tissue fatty acid composition profiles were not related to those of the corresponding dietary fats. The linolenic acid $(18: 3 n-3)$ contents were low in the liver and kidney tissues. Although linolenic acid comprises up to $12 \mathrm{~g} / 100 \mathrm{~g}$ total fatty acids in rapeseed oil, the linolenic acid contents in liver and kidney tissues were not significantly different between soyabean oil, rapeseed oil and fish oil groups. In addition, both eicosapentaenoic acid (20:5n-3) and docosahexaenoic acid (22:6n-3; DHA) were higher in the liver and kidney of mice fed on eicosapentaenoic acid- and DHA-rich fish oil.

Table 3. The fatty acid composition ( $\mathrm{g} / 100 \mathrm{~g}$ total fatty acids) of the livers and kidneys from NZB/W F1 female mice fed on different dietary fats in the early-feeding group*

(Mean values with their standard errors for four to six mice per dietary group)

\begin{tabular}{|c|c|c|c|c|c|c|c|c|c|c|}
\hline \multirow[b]{3}{*}{ Fatty acid } & \multicolumn{10}{|c|}{ Dietary fat } \\
\hline & \multicolumn{2}{|c|}{ Palm oil } & \multicolumn{2}{|c|}{ Lard-soyabean oil } & \multicolumn{2}{|c|}{ Soyabean oil } & \multicolumn{2}{|c|}{ Rapeseed oil } & \multicolumn{2}{|c|}{ Fish oil } \\
\hline & Mean & SE & Mean & SE & Mean & SE & Mean & SE & Mean & SE \\
\hline \multicolumn{11}{|l|}{ Liver } \\
\hline $16: 0$ & $23 \cdot 4^{\mathrm{b}}$ & 1.7 & $19 \cdot 3^{c}$ & 0.6 & $17 \cdot 7^{\mathrm{c}}$ & 0.9 & $17 \cdot 7^{\mathrm{c}}$ & 1.9 & $25 \cdot 9^{a}$ & $2 \cdot 3$ \\
\hline $16: 1 n-9$ & $3.9^{\mathrm{ab}}$ & 0.9 & $3 \cdot 0^{\mathrm{bc}}$ & 0.3 & $2 \cdot 3^{c}$ & 0.4 & $4 \cdot 6^{\mathrm{a}}$ & $1 \cdot 1$ & $3.7^{a b}$ & 0.7 \\
\hline $18: 0$ & $5 \cdot 5^{c}$ & 1.3 & $7 \cdot 4^{b}$ & 1.7 & $7 \cdot 2^{b}$ & $1 \cdot 7$ & $9 \cdot 4^{\mathrm{a}}$ & 0.7 & $11 \cdot 0^{\mathrm{a}}$ & 1.0 \\
\hline $18: 1 n-9$ & $47.9^{a}$ & 3.7 & $24 \cdot 7^{c}$ & 1.7 & $18 \cdot 2^{d}$ & 1.7 & $38 \cdot 3^{b}$ & 2.9 & $11.0^{\mathrm{e}}$ & 0.2 \\
\hline $18: 2 n-6$ & $9 \cdot 8^{d}$ & 0.8 & $28 \cdot 2^{b}$ & $3 \cdot 7$ & $36 \cdot 7^{a}$ & 4.9 & $16 \cdot 0^{c}$ & $2 \cdot 4$ & $9 \cdot 3^{d}$ & 0.7 \\
\hline $18: 3 n-3$ & \multicolumn{2}{|c|}{ ND } & 1.5 & 0.5 & 2.5 & 0.9 & 2.2 & 0.9 & \multicolumn{2}{|c|}{ ND } \\
\hline $20: 4 n-6$ & 7.6 & $2 \cdot 1$ & 8.4 & $2 \cdot 8$ & 8.7 & 3.1 & $5 \cdot 6$ & $2 \cdot 3$ & $7 \cdot 3$ & 1.1 \\
\hline $20: 5 n-3$ & \multicolumn{2}{|c|}{ ND } & \multicolumn{2}{|c|}{ ND } & \multicolumn{2}{|c|}{ ND } & $0 \cdot 6^{\mathrm{b}}$ & 0.3 & $7 \cdot 5^{\mathrm{a}}$ & $2 \cdot 8$ \\
\hline $22: 6 n-3$ & $2 \cdot 0^{\mathrm{c}}$ & 0.8 & $7 \cdot 5^{b}$ & 1.4 & $6 \cdot 6^{b}$ & 1.4 & $5 \cdot 7^{b}$ & $2 \cdot 2$ & $24 \cdot 2^{a}$ & 0.7 \\
\hline \multicolumn{11}{|l|}{ Kidney } \\
\hline $16: 0$ & $22 \cdot 4^{a}$ & 1.4 & $18 \cdot 7^{b c}$ & 1.2 & $17 \cdot 5^{c}$ & 1.2 & $16 \cdot 5^{d}$ & 0.7 & $19 \cdot 9^{b}$ & 1.0 \\
\hline $16: 1 n-9$ & $2 \cdot 4^{\mathrm{ab}}$ & 0.9 & $1.6^{c}$ & 0.4 & $1 \cdot 3^{c}$ & 0.3 & $1.8^{\mathrm{bc}}$ & 0.3 & $2 \cdot 5^{a}$ & 0.5 \\
\hline $18: 0$ & $12 \cdot 2^{b}$ & 3.2 & $13 \cdot 8^{b}$ & 0.9 & $16 \cdot 1^{\mathrm{a}}$ & 0.7 & $13 \cdot 3^{\mathrm{b}}$ & 0.9 & $16 \cdot 4^{\mathrm{a}}$ & 1.5 \\
\hline $18: 1 n-9$ & $23 \cdot 5^{a}$ & 6.0 & $16 \cdot 8^{b}$ & 3.7 & $11 \cdot 3^{c}$ & 1.4 & $21 \cdot 1^{a}$ & $2 \cdot 3$ & $11 \cdot 4^{\mathrm{c}}$ & 1.3 \\
\hline $18: 2 n-6$ & $10 \cdot 5^{d}$ & 1.4 & $19 \cdot 8^{b}$ & 1.9 & $22 \cdot 1^{\mathrm{a}}$ & 1.5 & $15 \cdot 8^{c}$ & 0.7 & $5 \cdot 6^{d}$ & 0.9 \\
\hline $18: 3 n-3$ & \multicolumn{2}{|c|}{ ND } & \multicolumn{2}{|c|}{ ND } & \multicolumn{2}{|c|}{ ND } & 1.9 & 0.7 & \multicolumn{2}{|c|}{ ND } \\
\hline $20: 4 n-6$ & $20 \cdot 2^{a}$ & 3.8 & $16 \cdot 2^{b}$ & 1.8 & $18 \cdot 9^{a b}$ & $2 \cdot 1$ & $16 \cdot 2^{b}$ & $2 \cdot 1$ & $12 \cdot 9^{c}$ & 0.9 \\
\hline $20: 5 n-3$ & \multicolumn{2}{|c|}{ ND } & \multicolumn{2}{|c|}{ ND } & & & \multicolumn{2}{|c|}{ ND } & 11.7 & 0.6 \\
\hline $22: 6 n-3$ & $8.8^{c}$ & 1.7 & $13 \cdot 1^{b}$ & $2 \cdot 3$ & $12 \cdot 8^{b}$ & $2 \cdot 1$ & $11.9^{b}$ & 0.7 & $19 \cdot 6^{a}$ & 1.0 \\
\hline
\end{tabular}

ND, not detectable.

a,b,c,d,e Mean values in the same row with unlike superscript letters were significantly different $(P<0.05$; one-way ANOVA and Duncan's multiple range test).

* Mice were fed for 5 months on a diet containing $200 \mathrm{~g}$ fat $/ \mathrm{kg}$. For details of diets and procedures, see pp. 332-333 and Table 1. 
Table 4. The fatty acid composition ( $\mathrm{g} / 100 \mathrm{~g}$ total fatty acids) of the livers and kidneys from NZB/W F1 female mice fed on different dietary fats in the late-feeding group*

(Mean values with their standard errors for four to six mice per dietary group)

\begin{tabular}{|c|c|c|c|c|c|c|c|c|c|c|}
\hline \multirow[b]{3}{*}{ Fatty acid } & \multicolumn{10}{|c|}{ Dietary fat } \\
\hline & \multicolumn{2}{|c|}{ Palm oil } & \multicolumn{2}{|c|}{ Lard-soyabean oil } & \multicolumn{2}{|c|}{ Soyabean oil } & \multicolumn{2}{|c|}{ Rapeseed oil } & \multicolumn{2}{|c|}{ Fish oil } \\
\hline & Mean & SE & Mean & SE & Mean & SE & Mean & SE & Mean & SE \\
\hline \multicolumn{11}{|l|}{ Liver } \\
\hline $16: 0$ & $24 \cdot 4^{a}$ & 1.5 & $21 \cdot 6^{b}$ & 0.9 & $19 \cdot 0^{c}$ & 1.0 & $18 \cdot 7^{c}$ & 1.6 & $24 \cdot 8^{a}$ & 1.4 \\
\hline $16: 1 n-9$ & 2.9 & 0.8 & 3.0 & 0.6 & $2 \cdot 7$ & 0.3 & 3.4 & 1.4 & 3.4 & 0.3 \\
\hline $18: 0$ & $13 \cdot 0^{a}$ & 1.5 & $10 \cdot 8^{a b}$ & $2 \cdot 3$ & $9 \cdot 4^{b}$ & 1.5 & $11.7^{\mathrm{ab}}$ & 3.9 & $11.9^{\mathrm{ab}}$ & 1.4 \\
\hline $18: 1 n-9$ & $32 \cdot 6^{a}$ & 4.5 & $24 \cdot 6^{\mathrm{b}}$ & $3 \cdot 1$ & $16 \cdot 4^{\mathrm{c}}$ & $3 \cdot 3$ & $32 \cdot 5^{\mathrm{a}}$ & 8.7 & $12 \cdot 1^{\mathrm{c}}$ & 1.5 \\
\hline $18: 2 n-6$ & $10 \cdot 7^{d}$ & 1.4 & $22 \cdot 0^{\mathrm{b}}$ & 0.7 & $37 \cdot 2^{a}$ & 4.2 & $14 \cdot 7^{\mathrm{C}}$ & 2.0 & $10 \cdot 4^{d}$ & 1.1 \\
\hline $18: 3 n-3$ & $2 \cdot 1^{\mathrm{b}}$ & 1.2 & $2 \cdot 1^{\mathrm{b}}$ & 0.3 & $3 \cdot 8^{a}$ & $0 . \overline{5}$ & $2 \cdot 5^{\mathrm{a}}$ & 0.6 & $2 \cdot 5^{\mathrm{a}}$ & 0.5 \\
\hline $20: 4 n-6$ & 9.4 & $2 \cdot 7$ & 8.8 & 2.6 & 5.9 & 1.4 & $8 \cdot 1$ & 4.4 & $7 \cdot 3$ & 0.7 \\
\hline $20: 5 n-3$ & \multicolumn{2}{|c|}{ ND } & \multicolumn{2}{|c|}{ ND } & \multicolumn{2}{|c|}{ ND } & $0.9^{b}$ & 0.5 & $8 \cdot 9^{a}$ & 0.4 \\
\hline $22: 6 n-3$ & $4.9^{b}$ & 1.5 & $7 \cdot 2^{b}$ & 1.6 & $5 \cdot 5^{b}$ & 1.2 & $7 \cdot 5^{\mathrm{b}}$ & $3 \cdot 7$ & $19 \cdot 7^{a}$ & 0.9 \\
\hline \multicolumn{11}{|l|}{ Kidney } \\
\hline $16: 0$ & $20 \cdot 3^{a}$ & 1.5 & $19 \cdot 0^{a b}$ & 0.8 & $17 \cdot 2^{\mathrm{cd}}$ & 1.3 & $15 \cdot 9^{d}$ & 1.2 & $18 \cdot 2^{b c}$ & 0.9 \\
\hline $16: 1 n-9$ & 1.7 & 0.3 & 1.5 & 0.1 & 1.4 & 0.5 & 1.8 & 0.4 & 1.8 & 0.2 \\
\hline $18: 0$ & $15 \cdot 6$ & $2 \cdot 1$ & 14.9 & 1.9 & $15 \cdot 2$ & 1.2 & 14.8 & 1.2 & 15.4 & 2.3 \\
\hline $18: 1 n-9$ & $17 \cdot 5^{\mathrm{a}}$ & 1.5 & $12 \cdot 9^{b}$ & 0.7 & $104^{c}$ & 0.6 & $17 \cdot 8^{a}$ & 1.7 & $9 \cdot 6^{c}$ & 0.7 \\
\hline $18: 2 n-6$ & $12 \cdot 0^{d}$ & 0.9 & $19 \cdot 3^{b}$ & 0.9 & $23 \cdot 8^{a}$ & 1.2 & $15 \cdot 9^{c}$ & 0.9 & $9 \cdot 3^{c}$ & $2 \cdot 3$ \\
\hline $18: 3 n-3$ & $1 \cdot 3^{\mathrm{b}}$ & 0.2 & $2 \cdot 2^{a}$ & 0.9 & $2 \cdot 3^{a}$ & 0.3 & $2 \cdot 2^{a}$ & 0.5 & $1 \cdot 8^{a}$ & 0.4 \\
\hline $20: 4 n-6$ & $22 \cdot 7^{\mathrm{a}}$ & 1.3 & $16 \cdot 7^{b}$ & 1.9 & $16 \cdot 8^{b}$ & 0.7 & $17 \cdot 0^{\mathrm{b}}$ & 1.4 & $12 \cdot 5^{\mathrm{c}}$ & 0.7 \\
\hline $20: 5 n-3$ & \multicolumn{2}{|c|}{ ND } & \multicolumn{2}{|c|}{ ND } & \multicolumn{2}{|c|}{ ND } & $1 \cdot 8^{b}$ & 0.5 & $11 \cdot 1^{\mathrm{a}}$ & 0.9 \\
\hline $22: 6 n-3$ & $9 \cdot 3^{c}$ & 1.4 & $13 \cdot 5^{\mathrm{b}}$ & 0.9 & $13 \cdot 0^{b}$ & 0.5 & $12 \cdot 8^{b}$ & $0 \cdot 7$ & $20 \cdot 3^{a}$ & 0.4 \\
\hline
\end{tabular}

ND, not detectable.

a,b,c,d Mean values in the same row with unlike superscript letters were significantly different $(P<0.05$; one-way ANOVA and Duncan's multiple range test).

* Mice were fed for 2 months on a diet containing $200 \mathrm{~g}$ fat $/ \mathrm{kg}$. For details of diets and procedures, see pp. 332-333 and Table 1.

Although both eicosapentaenoic acid and DHA were hardly detected in the other four dietary fats, DHA can be synthesized in the tissue and comprised about $6 \mathrm{~g} / 100 \mathrm{~g}$ total fatty acids in liver and $12 \mathrm{~g} / 100 \mathrm{~g}$ total fatty acids in kidney, except in the palm oil group. The tissue DHA composition in the palm oil group was significantly lower than those of the other four dietary groups $(P<0 \cdot 05)$.

Most of the fatty acid profiles for the early-feeding and late-feeding groups were very similar despite the difference in feeding period. The fatty acid composition profiles for the liver were similar to those for the kidney. Although there was a low level of arachidonic acid $(20: 4 n-6)$ in the dietary fat (Table 1), the arachidonic acid composition of liver tissue remained constant in both the early- and late-feeding groups. However, there was a significant difference in arachidonic acid composition of kidney among the five diet groups. Renal arachidonic acid compositions were significantly lower in mice fed on fish oil $(P<0.05)$ and was higher in mice fed on palm oil $(P<0.05)$ in both earlyand late-feeding groups.

\section{Serum triacylglycerol, cholesterol and phospholipid concentrations}

The serum lipids of mice fed on diets containing dietary fats varying in saturation is shown in Table 5. The average serum triacylglycerol concentration of each dietary group before diet treatment was $0.79-0.85 \mathrm{mmol} / \mathrm{l}$ at 2 months of age in the early-feeding group and $1.57-1.88 \mathrm{mmol} / \mathrm{l}$ at 4 months of age in the late-feeding groups. There were no significant differences between the five diet groups before diet treatment. However, when feeding different dietary fats serum triacylglycerol and cholesterol levels were the lowest in mice fed on the fish oil diet among the five dietary groups both in the early-feeding and late-feeding groups. For the late-feeding groups, serum triacylglycerol levels of mice fed on palm oil were highest among the five dietary groups. The effect of fish oil in lowering serum lipid level was observed after 1 month of feeding $(P<0.0001$ for early-feeding group and $P<0.01$ for late-feeding group). For the latefeeding group, serum cholesterol and phospholipid levels increased significantly $(P<0.05)$ at 6 months of age, after 1 month on the high-fat diet, except the mice fed on fish oil (Table 5 and Fig. 1(b)). There was a clear decrease in triacylglycerol, cholesterol and phospholipid levels in response to dietary fish oil. There was no significantly consistent effect among the other four dietary fats. However, the mice fed on palm oil, a relatively more saturated fat, tended to have elevated serum triacylglycerol, cholesterol and phospholipid levels in the late-feeding group (Table 5 and Fig. 1(b)).

\section{Anti-cardiolipin antibodies}

Mice were bled retro-orbitally every month, and sera were collected for determination of anti-cardioplipin antibody levels. In all five groups, both IgM and IgG anti-cardioplipin antibody tended to increase gradually with age, except the $\mathrm{IgG}$ titre of the late-feeding group (Fig. 2). Interestingly, IgG anti-cardiolipin antibodies in the fish oil group were significantly $(P<0.05)$ lower than those of the palm oil group in the early-feeding group (Fig. 2(a)). However, no 
Table 5. Serum triacylglycerol and cholesterol level of female NZB/W F1 mice fed on different dietary fats* (Mean values with their standard errors for ten to twelve mice per dietary group)

\begin{tabular}{|c|c|c|c|c|c|c|c|c|}
\hline \multirow{3}{*}{$\begin{array}{l}\text { Age (months)... } \\
\text { Dietary fat }\end{array}$} & \multicolumn{4}{|c|}{ Triacylglycerol (mmol/l) } & \multicolumn{4}{|c|}{ Cholesterol (mmol/l) } \\
\hline & \multicolumn{2}{|c|}{6} & \multicolumn{2}{|c|}{$8 \dagger$} & \multicolumn{2}{|c|}{6} & \multicolumn{2}{|c|}{$8 †$} \\
\hline & Mean & SE & Mean & SE & Mean & SE & Mean & SE \\
\hline $\begin{array}{l}\text { Early-feeding group } \\
\text { Palm oil } \\
\text { Lard-soyabean oil } \\
\text { Soyabean oil } \\
\text { Rapeseed oil } \\
\text { Fish oil } \\
\text { One-way ANOVA }\end{array}$ & $\begin{array}{c}1.09^{\mathrm{a}} \\
1.10^{\mathrm{a}} \\
0.98^{\mathrm{a}} \\
0.73^{\mathrm{b}} \\
0.58^{\mathrm{b}} \\
\quad P=\end{array}$ & $\begin{array}{l}0.06 \\
0.14 \\
0.07 \\
0.07 \\
0.04 \\
01\end{array}$ & $\begin{array}{r}2 \cdot 01 \\
2 \cdot 22 \\
2 \cdot 56 \\
1.52 \\
0.98 \\
P=\end{array}$ & $\begin{array}{r}0.41 \\
0.58 \\
1.06 \\
0.17 \\
0.07 \\
170\end{array}$ & $\begin{array}{l}5 \cdot 69^{\mathrm{ab}} \\
5 \cdot 49^{\mathrm{ab}} \\
4 \cdot 93^{\mathrm{b}} \\
6 \cdot 84^{\mathrm{a}} \\
2 \cdot 66^{\mathrm{c}} \\
\quad P=\end{array}$ & $\begin{array}{l}0.13 \\
0.17 \\
0.10 \\
0.97 \\
0.07 \\
01\end{array}$ & $\begin{array}{c}7.50^{\mathrm{ab}} \\
8.43^{\mathrm{ab}} \\
6.34^{\mathrm{bc}} \\
11.09^{\mathrm{a}} \\
3.11^{\mathrm{c}} \\
P=\end{array}$ & $\begin{array}{l}1.32 \\
1.79 \\
1.38 \\
1.63 \\
0.12 \\
09\end{array}$ \\
\hline $\begin{array}{l}\text { Late-feeding group } \\
\text { Palm oil } \\
\text { Lard-soyabean oil } \\
\text { Soyabean oil } \\
\text { Rapeseed oil } \\
\text { Fish oil } \\
\text { One-way ANOVA }\end{array}$ & $\begin{array}{c}2.36^{\mathrm{a}} \\
0.98^{\mathrm{b}} \\
0.93^{\mathrm{b}} \\
0.88^{\mathrm{b}} \\
0.72^{\mathrm{b}} \\
\quad P=\end{array}$ & $\begin{array}{l}0.61 \\
0.17 \\
0.15 \\
0.15 \\
0.07 \\
017\end{array}$ & $\begin{array}{l}3 \cdot 72^{\mathrm{a}} \\
1.78^{\mathrm{bc}} \\
3 \cdot 03^{\mathrm{ab}} \\
1.31^{\mathrm{bc}} \\
0 \cdot 83^{\mathrm{c}} \\
\quad P=\end{array}$ & $\begin{array}{r}1.45 \\
0.36 \\
0.83 \\
0.24 \\
0.06 \\
171\end{array}$ & $\begin{array}{c}10 \cdot 45^{\mathrm{a}} \\
8.36^{\mathrm{a}} \\
7.07^{\mathrm{ab}} \\
8.32^{\mathrm{a}} \\
3.67^{\mathrm{b}} \\
P=\end{array}$ & $\begin{array}{r}1.56 \\
1.51 \\
1.16 \\
1.34 \\
0.25 \\
61\end{array}$ & $\begin{array}{r}15.91^{\mathrm{a}} \\
11.68^{\mathrm{a}} \\
11 \cdot 17^{\mathrm{a}} \\
13.68^{\mathrm{a}} \\
3.43^{\mathrm{b}} \\
P=\end{array}$ & $\begin{array}{c}2.54 \\
1.67 \\
1.77 \\
1.75 \\
0.14 \\
01\end{array}$ \\
\hline
\end{tabular}

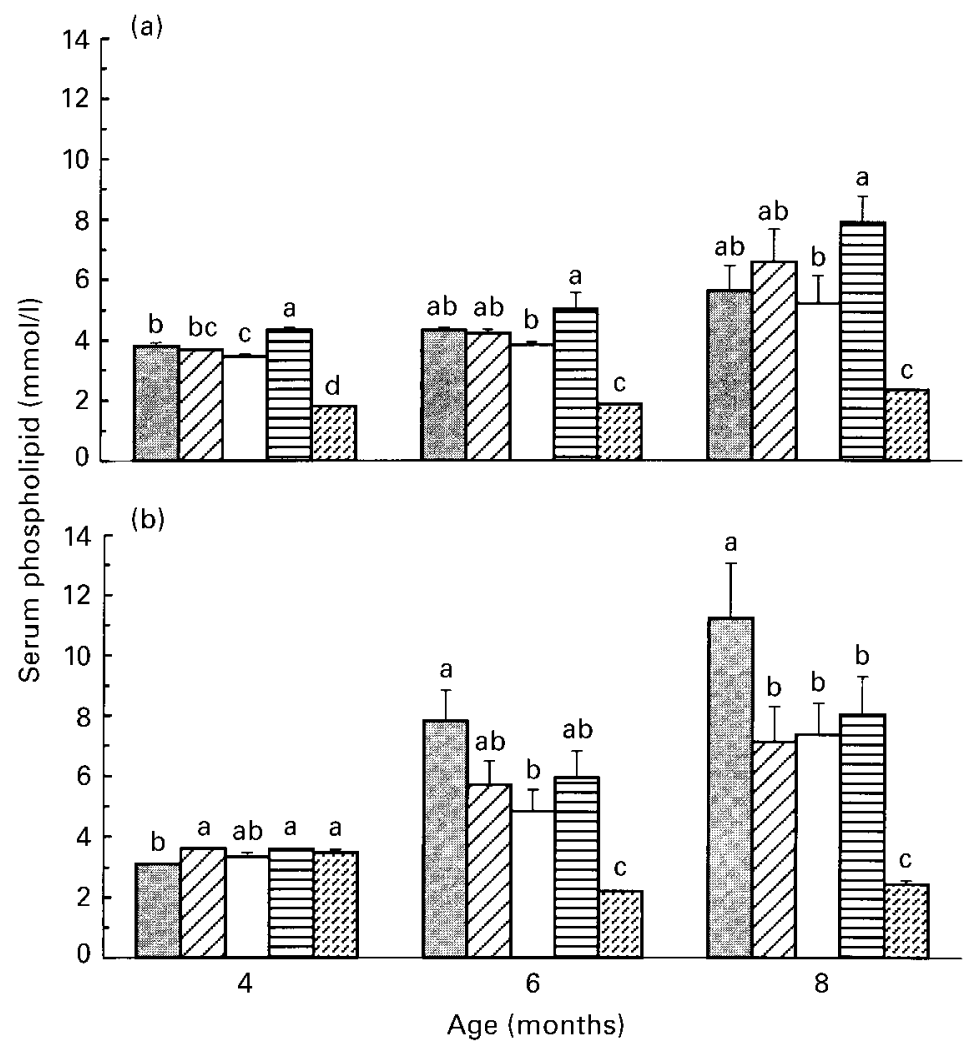

Fig. 1. Serum phospholipid levels of NZB/W F1 female mice in (a) the early-feeding group and (b) the late-feeding group, both fed on diets containing $200 \mathrm{~g}$ different fats $/ \mathrm{kg}$. The dietary fats were: palm oil ( $\square$ ), lard-soyabean oil ( $\square$ ), soyabean oil ( $\square$ ), rapeseed oil (目), and fish oil (国). Results are mean values with their standard errors for twelve mice per group, except the rapeseed oil group where ten mice per group were used. Data from 8-month-old mice were obtained from four to six surviving mice per dietary group. ${ }_{a, b, c}$ Means within age groups with unlike superscript letters were significantly different $(P<0.05$; Duncan's multiple range test). For details of diets and procedures, see pp. 332-333 and Table 1. 


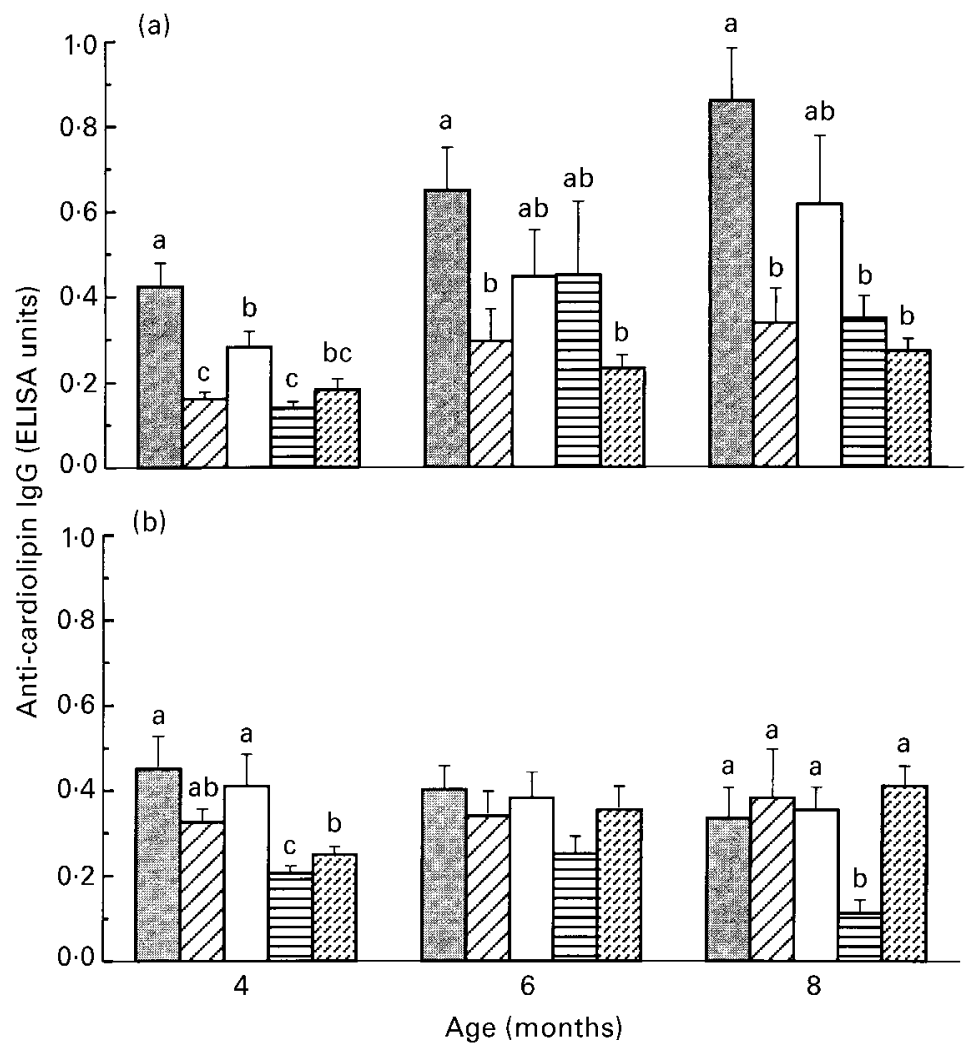

Fig. 2. Serum immunoglobulin (Ig) G anti-cardiolipin autoantibody levels of NZB/W F1 female mice in (a) the early-feeding group and (b) the late-feeding group fed on diets containing $200 \mathrm{~g}$ different fats $/ \mathrm{kg}$. The dietary fats were: palm oil $(\square)$, lard-soyabean oil (ख), soyabean oil $(\square)$, rapeseed oil (目), and fish oil (国). Each serum sample was diluted 100 -fold. Results are mean values with their standard errors for twelve mice per group, except the rapeseed oil group where ten mice per group were used. Data from 8-month-old mice were obtained from four to six surviving mice per dietary group. ${ }^{a, b, c}$ Means within age groups with unlike superscript letters were significantly different $(P<0.05$; Duncan's multiple range test). For details of diets and procedures, see pp. 332-333 and Table 1.

such pattern was noted in the late-feeding group (Fig. 2(b)). IgM anti-cardiolipin antibodies in mice fed on fish oil were lower compared with those of the other groups (Fig. 3). For late-feeding groups, serum anti-cardiolipin IgM levels significantly increased after the start of feeding the high-fat diet at 5 months of age $(P=0.0001$ for each group), except in mice fed on the fish oil $(P=0.5585)$. At the age of 8 months, surviving mice fed on fish oil had the lowest levels of IgM anti-cardiolipin autoantibodies among these five diet groups in both the early-feeding and late-feeding groups $(P<0.05)$. The profile of changes in serum anti-cardiolipin IgM was similar to that of serum phospholipid, therefore, the correlations between serum triacylglycerol, cholesterol and phospholipid levels and anti-cardiolipin antibody level were determined. It was found that $\operatorname{IgM}$ anti-cardiolipin antibody levels were correlated with serum phospholipid levels (Fig. 4); in contrast, no such correlation was found between IgG anti-cardiolipin antibody levels and phospholipid levels.

\section{Discussion}

Both human and murine SLE exhibit a characteristic spectrum of autoantibodies such as anti-erythrocyte, anti-DNA, anti-phospholipid antibodies (Theofilopoulos \& Dixon, 1981). Among these autoantibodies, antibodies to phospholipid are a heterogeneous group of autoantibodies found in the sera of patients with SLE or mice with lupus. Anticardiolipin antibodies have been shown to be closely related to anti-phospholipid syndrome, which includes venous and arterial thrombosis, thrombocytopenia, and recurrent fetal loss (Harris et al. 1983; Koike et al. 1984; Lockshin et al. 1985; McNeil et al. 1991). Studies suggest the level of IgG anti-cardiolipin antibodies is more closely related to the development of thrombosis and thrombocytopenia. In contrast, the anti-cardiolipin antibody of the IgM isotype has been linked to a haemolytic anaemia and livedo reticularis (Mackworth-Young, 1990).

In our previous study, levels of both IgG anti-cardiolipin and anti-ssDNA antibodies in the group of mice receiving $200 \mathrm{~g}$ fat $/ \mathrm{kg}$ were higher than those in the group receiving $50 \mathrm{~g}$ fat $/ \mathrm{kg}$ at 3 months of age (Lin et al. 1997b). The present study investigated the effect of different fats varying in their extent of saturation on the level of anti-cardiolipin antibody in autoimmune NZB/W F1 mice. The results suggested that the $\mathrm{IgG}$ anti-cardiolipin antibody level was lower in mice in the early-feeding group fed on fish oil compared with that of 


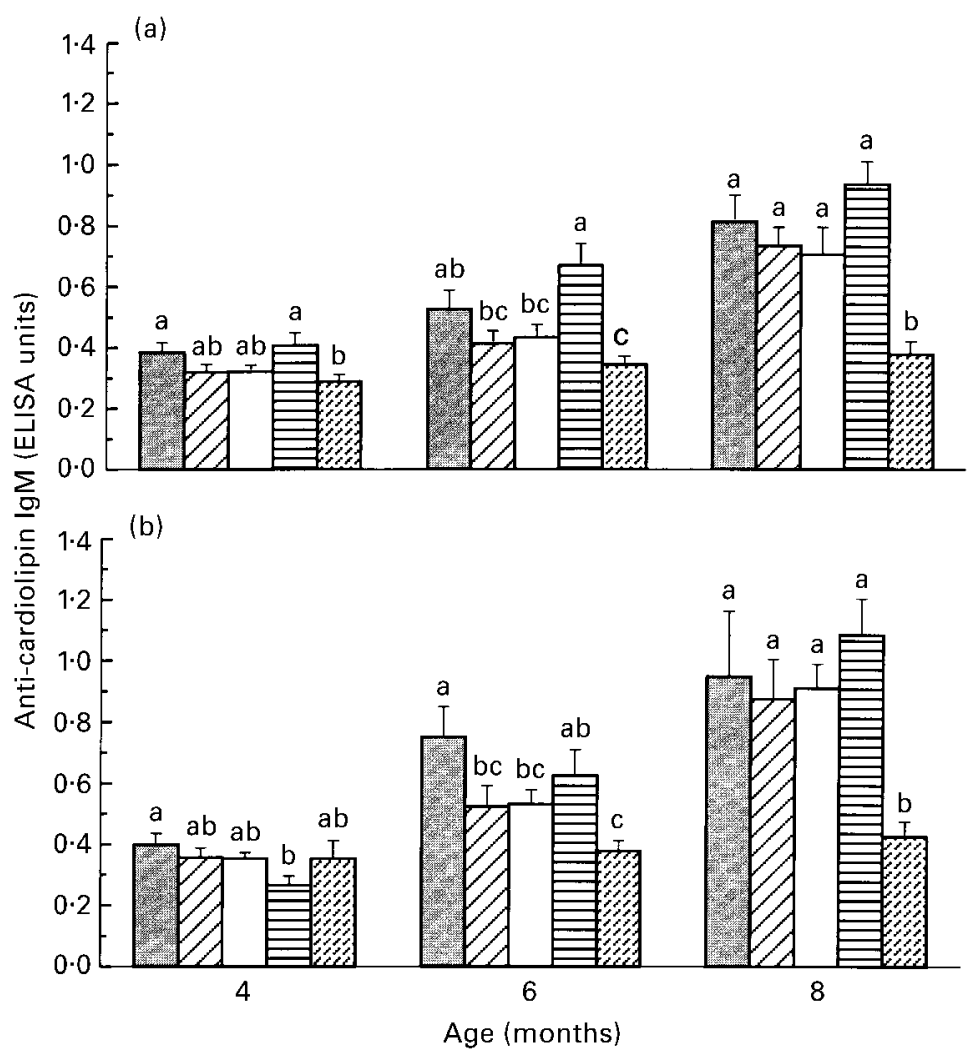

Fig. 3. Serum immunoglobulin (lg) M anti-DNA autoantibody levels of NZB/W F1 female mice in (a) the early-feeding group and (b) the late-feeding group fed on diets containing $200 \mathrm{~g}$ different fats $/ \mathrm{kg}$. The dietary fats are palm oil ( $\square$ ), lard-soyabean oil (『), soyabean oil $(\square)$, rapeseed oil (目), and fish oil (国). Each serum sample was diluted 400 -fold. Results are mean values with their standard errors for twelve mice per group, except the rapeseed oil group where ten mice per group were used. Data from 8-month-old mice were obtained from four to six surviving mice per dietary group. ${ }^{a, b, c}$ Means within age groups with unlike superscript letters were significantly different $(P<0.05$; Duncan's multiple range test). For details of diets and procedures, see pp. 332-333 and Table 1.

mice fed on palm oil. However, this effect was not observed in the late-feeding group. Furthermore, IgM anti-cardiolipin antibody level was lower in mice fed on fish oil in both the early- and late-feeding group.

There are several possible mechanisms for the effects observed with dietary fish oil. One study has suggested that increased serum triacylglycerol levels in patients with SLE might be closely related to production of anti-cardiolipin antibodies (MacGregor et al. 1992). Our findings showed that serum cholesterol, triacylglycerol and phospholipid levels were lower in mice fed on fish oil compared with those of the other groups. On the other hand, both the amount and content of dietary fatty acids can influence the composition of the cell membrane, and its recognition by the anti-phospholipid antibody (McNeil et al. 1991). Fish oil fatty acids may have just such an effect. The actual mechanism involved in the positive correlation between serum phospholipid levels and anti-phospholipid syndrome, therefore, needs to be further clarified. Although more studies are needed, the acyl composition of cardiolipin, which may play a critical role in the formation of antigenic determinants of B-cell (Levy et al. 1990; Qamar et al. 1990), can be influenced by various dietary fats (Berger et al. 1992). Thus, different dietary fats can affect the production of IgM anti-cardiolipin antibody and pathological damage in murine lupus. In the present study we have demonstrated a positive correlation between phospholipid level and IgM anti-cardiolipin antibody level, but not IgG anti-cardiolipin antibody. However, IgG is T-cell dependent and the antigenic determinants recognized by the T-cells are predominately protein in nature. It is suggested that $\mathrm{IgG}$ anti-cardiolipin antibody level is not related to serum phospholipid levels because the same protein source was used in the present study.

It is noteworthy that different dietary fats affected both serum and hepatic lipid contents in autoimmune-prone NZB/W F1 mice. Mice fed on a diet containing $250 \mathrm{~g}$ beef tallow $/ \mathrm{kg}$ were noted to have significantly higher serum $18: 2 n-6$ and $20: 4 n-6$ fatty acid compositions and a shorter lifespan compared with those of mice fed on menhaden oil (Prickett et al. 1981). The lower levels of hepatic $18: 2 n-6$ and kidney $18: 2 n-6$ and $20: 4 n-6$ fatty acid in the fish oil group may affect lipid metabolism and result in lower prostaglandin levels, which may subsequently alleviate the immune response (Synder et al. 1982; Santoli \& Zurier, 1989). Furthermore, higher levels of eicosapentaenoic acid 


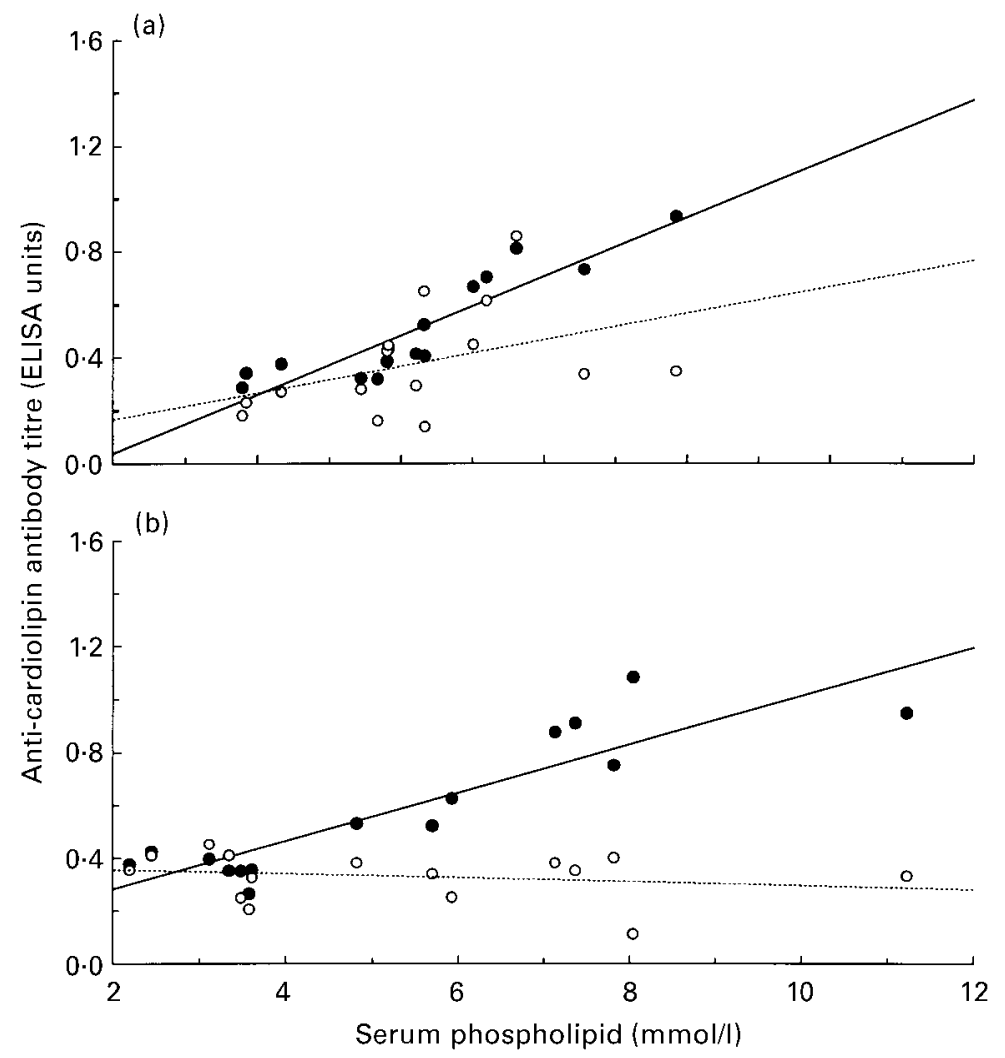

Fig. 4. Correlation between serum phospholipid level and immunoglobulin (Ig) G (O- $\bigcirc)$ or IgM (-) anti-cardiolipin antibodies level of NZB/W F1 mice in (a) the early-feeding and (b) the late-feeding groups. Values for the serum phospholipid levels and anti-cardiolipin antibodies titres were means for ten to twelve mice per dietary group from each age group. For $\lg \mathrm{M}$ anti-cardiolipin antibody in the early-feeding group $r 0.902, P<0.05$; for IgM anticardiolipin antibody in the late-feeding group $r 0.894, P<0.05$ (Pearson correlate test).

and DHA in mice fed on fish oil might also contribute to a lowering of inflammatory mediators during the autoimmune process (Prickett et al. 1983; Kelley et al. 1985; Robinson et al. 1985). The results show lower cholesterol and triacylglycerol levels in mice fed on fish oil in both the early- and late-feeding groups. This finding is consistent with reports of other groups (Ikeda et al. 1994; Geelen et al. 1995). In contrast, the hepatic phospholipid content was significantly higher in fish oil-fed mice in both the early-feeding and latefeeding groups. This finding contrasts with that of the serum phospholipid level in mice fed on dietary fish oil, which was lower compared with those of the other groups.

The present study investigated the influence of different dietary fats on both serum and tissue fatty acid composition and anti-cardiolipin antibody production. Lower serum cholesterol, triacylglycerol and phospholipid levels were found in mice fed on fish oil compared with those of the other groups. The composition of both liver and kidney fatty acids, such as oleic acid (18:1n-9) and linoleic acid (18:2n$6)$, can be affected by dietary fats with different fatty acid compositions. The effect on lipid metabolism of the age of feeding and the duration of feeding the experimental diet was not obvious. Dietary fish oil was also found to decrease the level of anti-cardiolipin antibody in autoimmune NZB/ W F1 mice. The findings demonstrated that the different dietary fats did exert different effects on lipid composition and anti-cardiolipin antibody level in autoimmune NZB $\times$ NZW F1 mice.

\section{Acknowledgements}

The authors are grateful for the helpful advice and for technical assistance from Professor Min-Hsiung Lee in fatty acid composition analysis. This study was supported by a grant from the National Science Council of the Republic of China; NSC 84-2321-B-002-026.

\section{References}

Berger A, Gershwin ME \& German JB (1992) Effects of various dietary fats on cardiolipin acyl composition during ontogeny of mice. Lipids 27, 605-612.

Chapkin RS, Akoh CC \& Miller CC (1991) Influence of dietary n-3 fatty acids on macrophage glycerophospholipid molecular species and peptidoleukotriene synthesis. Journal of Lipid Research 32, 1205-1213.

Eilat D, Zlotnick AY \& Fischel R (1986) Evaluation of the crossreaction between anti-DNA and anti-cardiolipin antibodies in SLE and experimental animals. Clinical and Experimental Immunology 65, 269-278.

Fernandes G, Bysani C, Venkatraman JT, Tomar V \& Zhao W 
(1994) Increased TGF- $\beta$ and decreased oncogene expression by $\omega-3$ fatty acids in the spleen delays onset of autoimmune disease in B/W F1 mice. Journal of Immunology 152, 5979-5987.

Fernandez ML, Vega S, Ayala MT, Shen H, Conde K, VergaraJimenez M \& Robbins A (1997) Vitamin C level and dietary fat saturation alter hepatic cholesterol homeostasis and plasma LDL metabolism in guinea pigs. Journal of Nutritional Biochemistry 8, 414-424.

Folch J, Lees M \& Sloane GM (1957) A simple method for the isolation and purification of total lipides from animal tissues. Journal of Biological Chemistry 226, 497-509.

Geelen MJH, Schoots WJ, Bijleveld C \& Beynen AC (1995) Dietary medium-chain fatty acids raise and (n-3) polyunsaturated fatty acids lower hepatic triacylglycerol synthesis in rats. Journal of Nutrition 125, 2449-2456.

Guo LSS, Hamilton RL, Ostald R \& Havel RJ (1982) Secretion of nascent lipoprotein and apolipoproteins by perfused livers of normal cholesterol-fed guinea pigs. Journal of Lipid Research 23, 543-555.

Harris EN, Gharavi AE, Boey ML, Patel BM, Mackworth-Young CG, Loizou S \& Hughes GRV (1983) Anticardiolipin antibodies: detection by radioimmunoassay and association with thrombosis in systemic lupus erythematosus. Lancet ii, 1211-1214.

Harris EN, Gharavi AE, Patel SP \& Hughes GRV (1987) Evaluation of the anticardiolipin antibody test: Report of an international workshop held April 1986. Clinical and Experimental Immunology 68, 212-215.

Hashimoto Y, Kawamura M, Ichikawa K, Suzuki T, Sumida T, Yoshida S, Matsuura E, Ikehara S \& Koike T (1992) Anticardiolipin antibodies in NEW $\times$ BXSB F1 mice: a model of antiphospholipid syndrome. Journal of Immunology 149, 10631068.

Ikeda I, Wakamatsu K, Inayoshi A, Imaizumi K, Sugano M \& Yazawa K (1994) $\alpha$-Linolenic, eicosapentaenoic and docosahexaenoic acids affect lipid metabolism differently in rats. Journal of Nutrition 124, 1898-1906.

Kelley VE, Ferretti A, Izui S \& Storm TB (1985) A fish oil diet rich in eicosapentaenoic acid reduces cyclooxygenase metabolites, and suppresses lupus in MRL-1pr mice. Journal of Immunology 134, 1914-1919.

Koike T, Sueishi M, Funaki H, Tomioka H \& Yoshida S (1984) Antiphospholipid antibodies and biological false positive serological test for syphilis in patients with systemic lupus erythematosus. Clinical and Experimental Immunology 56, 193-199.

Lee M-H, Wang M-L \& Min B-W (1990) Effects of methylation on determination of fatty acids. Food Science 17, 1-10.

Levy RA, Gharavi AE, Sammaritano LR, Habina L \& Lockshin MD (1990) Fatty acid chain is a critical epitope for antiphospholipid antibody. Journal of Clinical Immunology 10, 141-145.

Lin B-F, Chang S-C \& Wu W-M (1997a) Effects of high intake of dietary fat on liver microsomal P450 content, hepatic vitamin E and TBARS in autoimmune-prone NZB/W F1 mice. Journal of Nutritional Sciences 22, 15-31.

Lin B-F, Huang C-C, Chiang B-L \& Jeng S-J (1996) Dietary fat influences Ia antigen expression, cytokines and prostaglandin E2 production of immune cells in autoimmune-prone $\mathrm{NZB} \times \mathrm{NZW}$ F1 mice. British Journal of Nutrition 75, 711-722.

Lin B-F, Jeng S-J, Chiang B-L \& Huang C-C (1997b) Dietary fat affects lipids and anti-cardiolipin antibody levels in autoimmune-prone NZB/W F1 mice. British Journal of Nutrition 77, 657-669.
Lockshin MD, Druzin ML, Goei S, Qamar T, Magid MS, Janovic L \& Ferenc M (1985) Antibody to cardiolipin as a predictor of fetal distress or death in pregnant patients with systemic lupus erythematosus. New England Journal of Medicine 313, 152156.

MacGregor AJ, Dhillon VB, Binder A, Forte CA, Knight BC, Betterridge DJ \& Isenberg DA (1992) Fasting lipids and anticardiolipin antibodies as risk factors for vascular disease in systemic lupus erythematosus. Annals of Rheumatic Disease 51, $152-155$.

Mackworth-Young C (1990) Antiphospholipid antibodies: more than just a disease marker? Immunology Today 11, 60-65.

McNeil HP, Chesterman CN \& Krills SA (1991) Immunology and clinical importance of antiphospholipid antibodies. Advances in Immunology 49, 193-280.

National Research Council (1985) Guide for the Care and Use of Laboratory Animals. NIH Publication no. 85-23, revised ed. Bethesda, MD: National Institutes of Health.

Prickett JD, Robinson DR \& Steinberg AD (1981) Dietary enrichment with the polyunsaturated fatty acid eicosapentaenoic acid prevents proteinuria and prolongs survival in NZB/W F1 mice. Journal of Clinical Investigation 68, 556-559.

Prickett JD, Robinson DR \& Steinberg AD (1983) Effects of dietary enrichment with eicosapentaenoic acid upon autoimmune nephritis in female NZB $\times$ NZW F1 mice. Arthritis and Rheumatism 26, 133-139.

Qamar T, Gharavi AE, Levy RA \& Lockshin MD (1990) Lysophosphatidylethanolamine is the antigen to which apparent antibody to phosphatidylethanolamine binds. Journal of Clinical Immunology 10, 200-203.

Rauch J, Tannenbaum H, Stollar BD \& Schwartz S (1984) Monoclonal anti-cardiolipin antibodies bind to DNA. European Journal of Immunology 14, 529-534.

Robinson DR, Prickett JD, Polisson R, Steinberg AD \& Levine L (1985) The protective effect of dietary fish oil on murine lupus. Prostaglandins 30, 51-75.

Robinson DR, Xu LL, Knoell CT, Tateno S \& Olesiak W (1993a) Modification of spleen phospholipid fatty acid composition by dietary fish oil and by $\mathrm{n}-3$ fatty acid ethyl esters. Journal of Lipid Research 34, 1423-1434.

Robinson DR, Xu LL, Tateno S, Guo M \& Colvin RB (1993b) Suppression of autoimmune disease by dietary n-3 fatty acids. Journal of Lipid Research 34, 1435-1444.

Rupin A, Gruel Y, Watier H, Girard AC, Leroy J \& Bardos P (1991) ELISA for the detection of anticardiolipin antibodies. High specificity based on the use of adult bovine serum as buffer and systematic subtraction of non-specific binding. Journal of Immunological Methods 138, 225-231.

Santoli D \& Zurier RB (1989) Prostaglandin E precursor fatty acid inhibits human IL-2 production by a prostaglandin E-independent mechanism. Journal of Immunology 143, 1303-1309.

Snyder DS, Beller DI \& Unanue ER (1982) Prostaglandins modulate macrophage Ia expression. Nature 299, 163-165.

Soloni FG (1971) Simplified manual micromethod for determination of serum triglycerides. Clinical Chemistry 17, 529-534.

Stewart JCM (1980) Colorimetric determination of phospholipids with ammonium ferrothiocyanate. Analytical Biochemistry 104, 10-14.

Theofilopoulos AN \& Dixon FJ (1981) Etiopathogenesis of murine SLE. Immunology Review 55, 179-216.

Theofilopoulos AN, Kofler R, Singer PA \& Dixon FJ (1989) Molecular genetics of murine lupus models. Advances in Immunology 46, 61-109. 